\title{
A new record of Azadinium spinosum (Dinoflagellata) from the tropical Mexican Pacific
}

\author{
Un nuevo registro de Azadinium spinosum (Dinoflagellata) en el Pacífico tropical Mexicano
}

\author{
David U. Hernández-Becerril ${ }^{1}$, Sofía A. Barón-Campis² and Sergio Escobar-Morales ${ }^{3,4}$ \\ ${ }^{1}$ Instituto de Ciencias del Mar y Limnología, Universidad Nacional Autónoma de México, Ciudad Universitaria, Apdo. postal \\ 70-305, México, D.F. 04510 México.dhernand@cmarl.unam.mx \\ ${ }^{2}$ Instituto Nacional de Pesca, SAGARPA, Pitágoras 1320, México, D.F. 03310, México \\ ${ }^{3}$ Posgrado en Ciencias del Mar y Limnología, Universidad Nacional Autónoma de México, México D.F., México \\ ${ }^{4}$ Unidad de Ciencias del Agua, Centro de Investigación Científica de Yucatán (CICY), Cancún, Q.R. 77500, México
}

\begin{abstract}
The species Azadinium spinosum, a small thecate dinoflagellate, originally and recently described from the North Sea, was found for the first time in the tropical Pacific coast of Mexico. Description by light and scanning electron microscopy and abundance data are here provided. The morphology of the species agrees with the original description, including size, shape, presence of posterior spine and tabulation details. Less than 300 cells $\mathrm{L}^{-1}$ were found in one station in the Pacific coast of Mexico. This species has been recognized as a producer of azaspiracid toxins (AZAs) in the North Sea, although no toxin analysis has been made as yet in Mexican waters.
\end{abstract}

Key words: Azadinium spinosum, Azaspiracid toxins, Dinoflagellates, Mexican Pacific, new record

\section{INTRODUCTION}

Dinoflagellates are an extended and a very important protist group of the marine phytoplankton, because of their diversity, abundance, ecological role and potential toxicity. In the Mexican Pacific Ocean, most of the studies about this group have been dedicated to the microplankton fraction and species that produce red tides or toxins. A check list of the dinoflagellates from the Mexican Pacific listed 605 free-living species (Okolodkov \& Gárate-Lizárraga 2006), but still many new records and even new species have been recently described (Hernández-Becerril \& Bravo-Sierra 2004a, 2004b, Hernández-Becerril et al. 2008, Gárate-Lizárraga 2009, Gárate-Lizárraga et al. 2011).

During the course of phytoplankton biodiversity surveys, two oceanographic cruises in the coasts of the Mexican Pacific were carried out, and a new record of a small thecate dinoflagellate, later identified as Azadinium spinosum, a nanoplanktonic species recently described from the North Sea (Tillmann et al. 2009) was made. This small thecate dinoflagellate $(12-16 \mu \mathrm{m})$, is known as a producer of azaspiracid toxins (AZAs) (Tillmann et al. 2009, Salas et al. 2011). The purposes of this study are to annotate a new report of this species in the tropical Pacific of Mexico, and provide a description of the specimens found in the area and information on its abundance and distribution.

\section{Materials AND MEthods}

Phytoplankton was sampled (bottle and net samples) during two oceanographic cruises. One cruise was carried out along coasts off the tropical Mexican Pacific (cruise 'Tehua-V', February, 2008), with findings of the species in at least two localities (Fig. 1). The other cruise (cruise 'MareaR II', 26 April - 7 May, 2010) was performed in the central Mexican Pacific, where the species was detected and counted in only one point (Fig. 1).

A total of 35 bottle samples were taken at different depths, including surface and the maximum chlorophyll subsurface layer (MCSL). Two procedures were followed: surface samples of the first cruise were concentrated by passive filtration (using only gravity and cellulose filters of $1.2 \mu \mathrm{m}$ pore), and then fixed with $1 \%$ glutaraldehyde. For the second cruise, bottle samples were taken from different depths at fixed stations, subsampled $(250 \mathrm{~mL})$ and then fixed with Lugol's solution. Unfortunately, no samples were taken nor fixed to carry out molecular analysis.

Lugol's fixed samples were analyzed following the inverted microscope technique (Utermöhl) (Edler \& Elbrächter 2010), using chambers of either 25 or $50 \mathrm{~mL}$, settled down for $24 \mathrm{~h}$. Identification and counting were made in cross-transects and density of phytoplankters was calculated using the formula as recommended by 


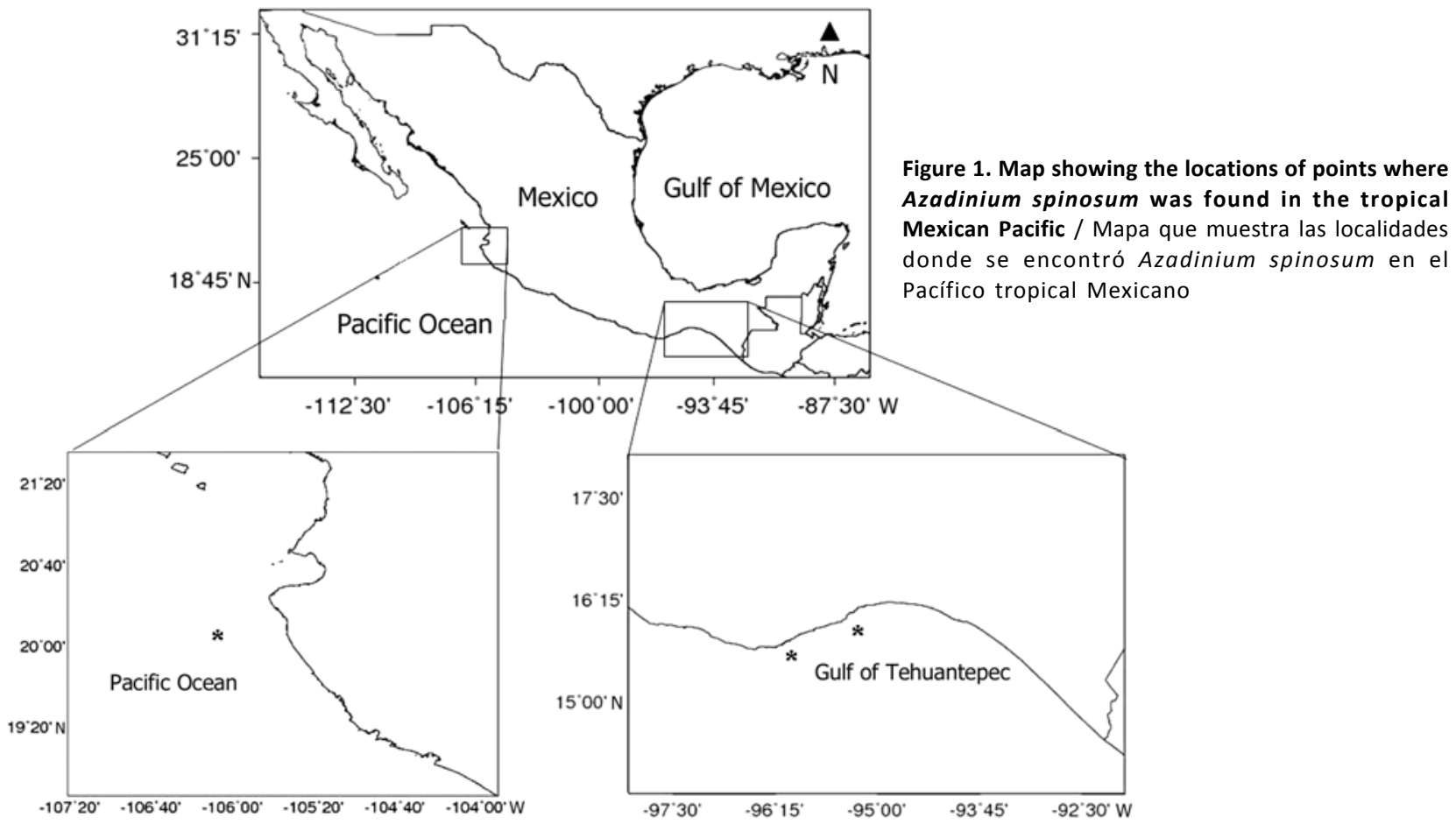

Andersen \& Throndsen (2003). For additional observations by electron microscopy, glutaraldehyde fixed samples were dehydrated (through alcohol series), critically point-dried, mounted upon an aluminum stub, coated with gold and then observed by SEM (JEOL JSM 6360LV).

\section{Results}

Description of Azadinium spinosum Elbrächter et Tillmann

Reference: Tillmann et al. 2009, p. 66, figs. 1 A-E, 2 A-C, 3 A-E, 4 A-D, 5 A-E, 6 A-F; Salas et al. 2011, p. 778, figs. 2 A-C, figs. 3 A-D.

The species was found solitary (Fig. 2 a-e). The cells have an elliptic outline, elongate, and are slightly dorsoventrally depressed (Fig. 2 a-e). The epitheca is conical, larger than the hypotheca, which is also conical but slightly curved at the posterior end, and cingulum is wide (up to $1 / 4$ of the cell length) and excavated (Fig. 2 a-e). The epitheca shows a conspicuous apical pore complex (APC), not protruding (Fig. 2 a-e). The apical plate (1') is rhomboid (Fig. 2c), the second anterior intercalary (plate 2a) is small, four-sided, and almost square to rhomboid (Fig. 2d). The hypotheca is slightly asymmetrical and has a very fine and short antapical spine (Fig. 2b, d, e). The cingulum is wide, excavate and descending (Fig. 2c). The cingular lists are poorly-developed, and sulcal lists are lacking (Fig. 2c-e). There are very few poroids scattered in the theca, especially two are present in the third apical plate (3'), and a row of poroids parallel and just below the lower cingular list (Fig. 2d, e).

Thecal tabulation of specimens found in this study shows the same arrangement as described originally: apical pore complex (APC), 4', 3a, 6", 6C, ?S, 6"', 2"’”.

Measurements are: 10.8-12.8 $\mu \mathrm{m}$ length, 7.5-7.8 $\mu \mathrm{m}$ width $(n=7)$.

A total of 12 specimens of Azadinium spinosum were detected (only 7 measured): 4 in material for SEM and the rest in settled material for counting for inverted microscope. The species was found at 3 locations in the Mexican Pacific (Fig. 1), but only in one location (Station 10, $10 \mathrm{~m}$ depth) specimens of Azadinium spinosum where found and counted, together with other phytoplankton species (Table 1); all other samples yielded no specimens of the species. Relatively low numbers of the species were recorded, 289 cells L $^{-1}$ in April, 2010 (Table 1). 
Figure 2. Azadinium spinosum from the tropical Mexican Pacific. Light microscopy: a) Specimen with protoplasm, including chloroplast, b) Specimen showing the outline of the cell, epi- and hypotheca, cingulum and a posterior short spine (arrow). SEM: c) Ventral view of a cell, with a wide cingulum, d) Cell in dorsal view, showing the second intercalary plate, 2a $\left({ }^{*}\right)$ and posterior spine (arrow), e) Specimen in lateral view, with the posterior spine (arrow) / Azadinium spinosum del Pacífico tropical Mexicano. Microscopía de luz: a) Espécimen con protoplasma, incluyendo cloroplastos, b) Espécimen mostrando el contorno de la célula, epi- e hipoteca, cingulum y una espina posterior corta (flecha). MEB: c) Vista ventral de una célula con cingulum amplio, d) Célula en vista dorsal mostrando la segunda placa intercalar anterior $2 a\left({ }^{*}\right)$ y una espina posterior (flecha), e) Espécimen en vista lateral con una espina posterior (flecha)
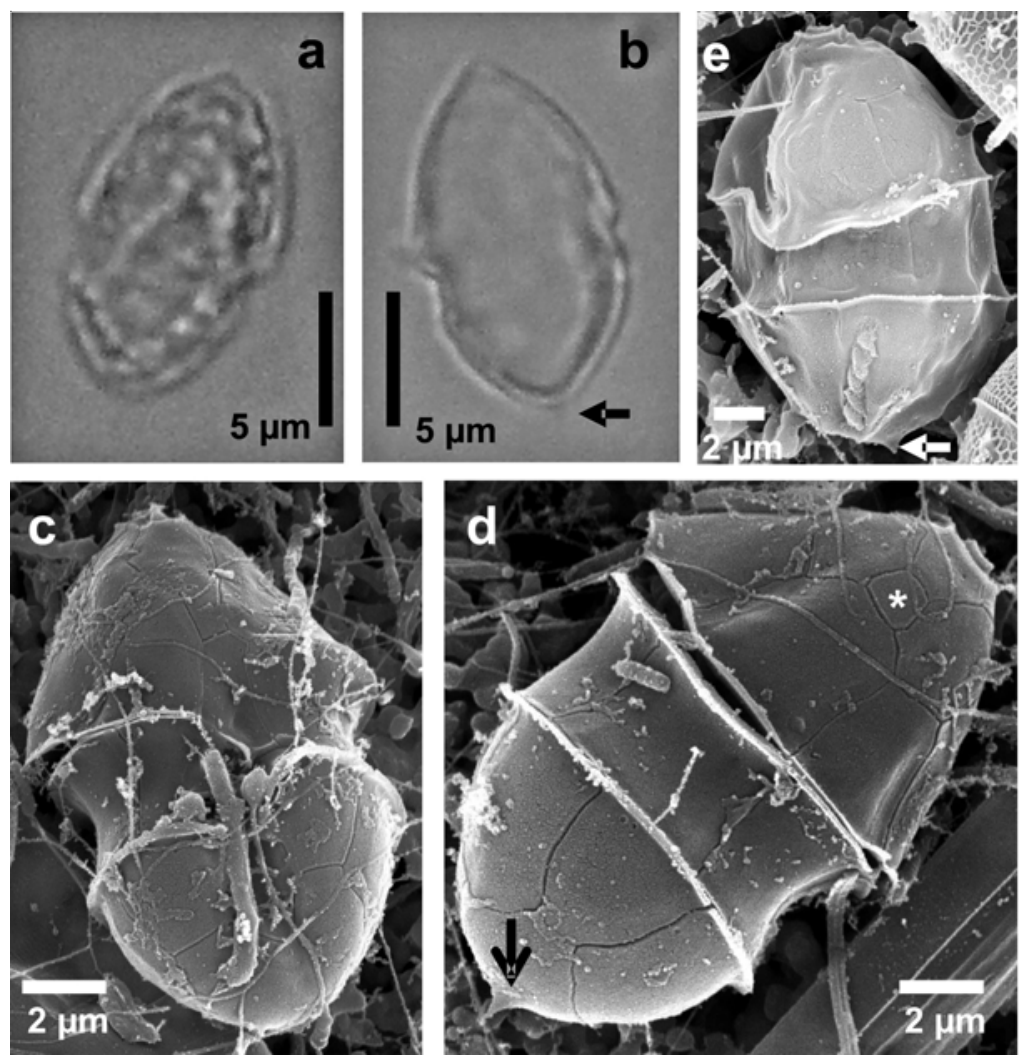

Table 1. Species composition and abundance at Station 10 (10 m depth), April, 2010, where Azadinium spinosum was detected and counted / Composición y abundancia de especies para la Estación 10 (10 m profundidad) en abril 2010, donde Azadinium spinosum fue encontrado y cuantificado

\begin{tabular}{lr}
\hline Species & cells L \\
\hline Chaetoceros curvisetus & 72,159 \\
Chaetoceros socialis & 226,097 \\
Cylindrotheca closterium & 3,598 \\
Detonula pumila & 70,234 \\
Leptocylindrus danicus & 14,432 \\
Lioloma pacificum & 7,697 \\
Proboscia alata & 962 \\
Pseudonitzschia delicatissima & 10,583 \\
P. fraudulenta & 21,167 \\
P. pungens & 65,424 \\
P. multistriata & 962 \\
\hline
\end{tabular}

\begin{tabular}{lr}
\hline Species & cells $\mathrm{L}^{-1}$ \\
\hline Rhizosolenia imbricata & 4,811 \\
Thalassionema nitzschioides & 962 \\
Dinoflagellates & \\
Azadinium spinosum & \\
Oxytoxum variabile & 289 \\
Prorocentrum gracile & 3,848 \\
Scrippsiella trochoidea & 289 \\
Ciliates & 1,924 \\
Myrionecta rubra & \\
& \\
\hline
\end{tabular}




\section{Discussion}

The morphology of the specimens of Azadinium spinosum found in the Mexican Pacific agrees well with the original description of the species, including tabulation (Tillmann et al. 2009), and posterior descriptions (Salas et al. 2011, Akselman \& Negri 2012). The shape of the species in this study is similar to the original description, although is slightly smaller than those originally described (10.8-12.8 $\mu \mathrm{m}$ length in our material against 12.3-15.7 $\mu \mathrm{m}$ length of the North Sea material). Additionally, as we studied fixed material, the single chloroplast and the pyrenoid described for the species were not clearly defined at the magnification utilised (Fig. 2a).

We were not able to observe the ventral pore located in the first apical plate (1'), as it was justly covered by a small particle. The second intercalary plate (2a) was identical to the one described originally, which is typical for its size and shape in the specimens studied here. Finally, the posterior delicate spine was seen either in LM and SEM.

We also compared our specimens with the closely related species Azadinium obesum Tillmann et Elbrächter and Azadinium poporum Tillmann et Elbrächter (Tillmann et al. 2010, 2011), and we are certain that the species corresponds to A. spinosum, for all morphological characters observed.

Additionally, some Heterocapsa or Scrippsiella species may superficially resemble Azadinium spinosum, especially in shape and size, such as $H$. rotundata (Lohmann) Hansen, although in the latter the epitheca has a different shape, is larger, and lacks an antapical spine (Iwataki 2008), or S. precaria Montresor et Zingone, which is about the same size and shape, has a small square second anterior intercalary plate (plate 2a), similar to $A$. spinosum, but with a narrower cingulum and has no antapical spine (Montresor \& Zingone 1988).

The phylogenetic position of the genus Azadinium is controversial since its original description (Tillmann et al. 2009), when the authors mentioned the uncertainty of classifying the genus into ordinal affiliation and the possibility that it might be included in a new order of dinoflagellates, according to 2 molecular phylogenies (using markers based on rDNA and COI), which was confirmed later (Salas et al. 2011).

Azadinium spinosum was not only identified, but also counted in locations from the Mexican Pacific coasts.
The numbers are considered low, with less than 300 cells $\mathrm{L}^{-1}$ in one station, at $10 \mathrm{~m}$ depth, so the species may be considered unabundant and rare. This may not represent any potential danger in regards to high concentration of azaspiracid toxins (AZAs), although no toxin analysis was or has been made yet. Azadinium spinosum was associated with a small phytoplankton bloom, where the diatom Chaetoceros socialis and the ciliate Myrionecta rubra were the dominant species, whereas species of the diatom genus Pseudo-nitzschia (some species are considered to be toxic) also yielded important densities (Table 1).

The species is a new record for the study area and the Pacific Ocean, although the genus Azadinium and the species $A$. cf. poporum have been already found in the Pacific Ocean (Korea) (Potvin et al. 2012). Its distribution has increased, not only occurring in temperate and cold northern waters (North Sea) (Tillmann et al. 2009) and Ireland (Salas et al. 2011), the southwestern Atlantic in Argentina (Akselman \& Negri 2012), or the north Pacific (Korea) (Potvin et al. 2012), but also in tropical waters: the Pacific coast of Mexico.

\section{ACKNOWLEDGMENTS}

We would like to thank Dr. Urban Tillmann for the interesting discussions about the identification of the species. We also would like to recognize Yolanda Hornelas (ICMyL, UNAM) for her assistance in SEM. Partial support for this study has been given by project No. IN226209-3 (PAPIIT, DGAPA, Universidad Nacional Autónoma de México). SE. M. initially received a fellowship by CONACYT and then by the same project. Three anonymous reviewers helped to improve the paper.

\section{LITERATURE CITED}

Akselman R \& RM Negri. 2012. Blooms of Azadinium cf. spinosum Elbrächter et Tillmann (Dinophyceae) in northern shelf waters of Argentina, Southwestern Atlantic. Harmful Algae 19: 30-38.

Andersen $\mathbf{P}$ \& $\mathbf{J}$ Throndsen. 2003. Estimating cell numbers. In: Hallegraeff GM, DM Anderson \& AD Cembella (eds). Manual on harmful marine microalgae, pp. 99-129. UNESCO Publishing, Paris.

Edler L \& M Elbrächter. 2010. The Utermöhl method for quantitative phytoplankton analysis. In: Karlson B, C Cusack \& E Bresnan (eds). Microscopic and molecular methods for quantitative phytoplankton analysis, pp. 1320. UNESCO Publishing, Paris. 
Gárate-Lizárraga I. 2009. First record of Ceratium dens (Dinophyceae) in the Gulf of California. CICIMAR Oceánides 24: 167-173.

Gárate-Lizárraga I, F García-Domínguez, B Pérez-Cruz \& JA Díaz-Ortiz. 2011. First record of Cochlodinium convolutum and C. helicoides (Dinophyceae: Gymnodiniaceae) in the Gulf of California. Revista de Biología Marina y Oceanografía 46: 495-498.

Hernández-Becerril DU \& E Bravo-Sierra. $2004 a$. Observations on a rare planktonic dinoflagellate, Dinofurcula cf. ultima (Dinophyceae), from the Mexican Pacific. Phycologia 43: 341-345.

Hernández-Becerril DU \& E Bravo-Sierra. 2004b. New records on planktonic dinoflagellates (Dinophyceae) from the Mexican Pacific Ocean. Botanica Marina 47: 417-423.

Hernández-Becerril DU, JGA Ceballos-Corona, K Esqueda-Lara, MA Tovar-Salazar \& D León-Álvarez. 2008. Marine planktonic dinoflagellates of the Order Dinophysiales (Dinophyta) from coasts of the tropical Mexican Pacific, including two new species of the genus Amphisolenia. Journal of the Marine Biological Association of the United Kingdom 88: 1-15.

Iwataki M. 2008. Taxonomy and identification of the armored dinoflagellate genus Heterocapsa (Peridiniales, Dinophyceae). Plankton and Benthos Research 3: 135-142.

Montresor M \& A Zingone. 1988. Scrippsiella precaria sp. nov. (Dinophyceae), a marine dinoflagellates from the Gulf of Naples. Phycologia 27: 387-394.
Okolodkov Y \& I Gárate-Lizárraga. 2006. An annotated checklist of dinoflagellates (Dinophyceae) from the Mexican Pacific. Acta Botánica Mexicana 74: 1-154.

Potvin E, HJ Jeong, NS Kang, U Tilmann \& B Krock. 2012. First report of the photosynthetic dinoflagellate genus Azadinium in the Pacific Ocean: morphology and molecular characterization of Azadinium cf. poporum. Journal of Eukaryotic Microbiology 59: 145-156.

Salas R, U Tilmann, U John, J Kilcoyne, A Burson, C Cantwell, P Hess, T Jauffrais \& J Silke. 2011. The role of Azadinium spinosum (Dinophyceae) in the production of azaspiracid shellfish poisoning in mussels. Harmful Algae 10: 774-783.

Tillmann U, M Elbrächter, B Krock, U John \& A Cembella. 2009. Azadinium spinosum gen. et sp. nov. (Dinophyceae) identified as a primary producer of azaspiracid toxins. European Journal of Phycology 44: 63-79.

Tillmann U, M Elbrächter, B Krock, U John \& A Cembella. 2010. Azadinium obesum (Dinophyceae), a new nontoxic species in the genus that can produce azaspiracid toxins. Phycologia 49: 169-182.

Tillmann U, M Elbrächter, U John \& B Krock. 2011. A new non-toxic species in the dinoflagellate genus Azadinium: Azadinium poporum sp. nov. European Journal of Phycology 46: 74-87.

Received 21 March 2012 and accepted 10 July 2012

Associate Editor: Pilar Muñoz M. 